\title{
WATER RESISTANT PLYWOOD OF INCREASED ELASTICITY PRODUCED FROM EUROPEAN WOOD SPECIES
}

\author{
Tomasz Biadaea, Rafae Czarnecki, Dorota Dukarska \\ Poznan University of Life Sciences \\ Poznan, Poland
}

(Received February 20I9)

\begin{abstract}
The paper investigates the possibility of producing the water-resistant plywood of increased elasticity with use of veneers attained from European wood species, such as alder, birch, beech, pine as well as linden, poplar, willow and spruce. Plywood was produced in two variants. Variant I of plywood was made from various wood species, yet the veneers were of the same thickness. In variant II the centre layer in each case was made from $1 \mathrm{~mm}$ thick pine veneer and the face layers were made from $1.4 \mathrm{~mm}$ thick veneers of various wood species. The produced plywood was subjected to tests on modulus of rupture, modulus of elasticity and tensile strength, bond quality and compression ratio. Specific values of modulus of rupture and modulus of elasticity were also determined taking into consideration the differences in the thickness of applied veneers. Based on these investigations, the authors concluded that, regardless of the manufacturing method, the highest values of modulus of rupture as well as modulus of elasticity and bond quality are achieved for plywood made from linden, poplar, willow and spruce. The change in the plywood structure (variant II) resulted in a considerable decrease in the values of modulus of rupture and modulus of elasticity (and their specific values) both parallel and across the grain. The lowest values of these parameters were obtained for poplar, linden and willow plywood. What is more, as a result of the applied procedure the bond quality of the produced plywood increased and the compression ratio was reduced. Taking the above into account, we can assume that linden, poplar and willow wood is an optimum choice for the face veneers of plywood with increased elasticity. The centre layer of this kind of plywood can be made from pine veneer of lesser thickness.
\end{abstract}

KEYWORDS: Plywood, wood species, flexible plywood, water resistance.

\section{INTRODUCTION}

The current trends in the wood based materials industry are aimed at searching for new innovative technological solutions, such as using materials that have not been applied so far in the 
process of producing or creating new hybrid materials. These activities are purposed to restrain the production costs, to obtain a new material of better or pre-designed properties or to widen the applicability of the traditional materials.

Due to high production volume as well as the characteristics of the manufacturing process, it is necessary to supply a large quantity of good quality timber. In the production of traditional plywood the most commonly used wood species are birch, alder, beech, pine and spruce. So far, the results of investigations have shown that both plywood and LVL can be manufactured with use of not only these wood species, but also plantation wood species. Investigations by $\mathrm{Bal}$ and Bektas $(2012,2014)$ and Bal (2016) prove that mechanical properties (bending strength and modulus of elasticity) of LVL and plywood manufactured from eucalyptus are comparable to those made from beech. Research works conducted by Iwakiri et al. $(2006,2013)$ also confirm that various types of eucalyptus wood can be successfully applied in the production of plywood. Satisfactory results have also been attained for three kinds of pine, i.e. Pinus maximinoi, Pinus oocarpa and Pinus tecunumannii which also grow in plantations (Iwakiri et al. 2012). Plywood produced with their use is characterized by bending strength and modulus of elasticity whose values are comparable to those obtained for commercial products made from Pinus taeda. Iwakiri et al. (2018) have also found out that another species of great potential is cypress Cupressus torulosa, which either alone or combined with pine veneer can be used in the production of plywood of good strength properties and high bond quality. An alternative to fast-growing species which can be used in the production of plywood is Gmelina arborea. Investigations by Shukla and Kamden (2008) prove that low-density wood such as silver maple, yellow poplar and aspen can also be effectively applied in the production of LVL. According to Knudson and Brunette (2015) yellow poplar (Liriodendron tulipifera L.) as well as red alder (Alnus rubra Bong.) which are used in the production of interior design elements can be substituted by hybrid Walker poplar ( $P$. deltoides $P$. petrowskyana) which is characterized by low density, similar to that of aspen, i.e. $390 \mathrm{~kg} \cdot \mathrm{m}^{-3}$. The use of veneers attained from this this kind of poplar, either alone or combined with other species such as aspen or spruce, makes it possible to produce high quality plywood. In case of LVL, it is advisable to use this kind of wood for centre layers as the strength parameters of the ready product are better then. According to Öncel et al. (2019) the combination of poplar and other wood species, such as alder, spruce of pine also favourably affects the bond quality in plywood as determined by their tensile-shear strength after preliminary procedures (soaking in water and boiling).

The final properties of plywood, such as bending strength and modulus of elasticity, are affected by not only the wood species veneers are made from but also by wood density, type of adhesive, thickness and number of veneers and the effect of their growth conditions, steaming and drying temperatures (Peker and Tan 2014). An alteration in mechanical properties can also be achieved by changing the position of veneer in the plywood structure (Kljak et al. 2006, 2007, Popovska et al. 2017). This principle is used e.g. in the production of flexible plywood.

In the process of manufacturing flexible plywood, apart from the type of wood, the diversification of veneer thickness in the particular layers is the key factor. The elasticity of the product grows as the face layer thickness/core layer thickness coefficient increases. In the production of flexible plywood manufacturers use wood of exotic species, e.g. okoume (gaboon), ceiba (fuma) and balau (meranti), which generates high costs for the European plywood industry in terms of both materials and transport. Ecological aspect is also significant. Owing to the decrease in the consumption of exotic wood species, the scale of illegal logging of rainforests may be reduced and the biodiversity and climatic conditions on Earth may improve. That is why, researchers have begun to investigate the possibility of substituting exotic timber with cheaper 
domestic species in the production of flexible plywood and other wood based materials. The growing demand for this type of products indicates how significant and valid the subject is. As flexible plywood offers individual and innovative solutions, for a number of years it has been used in the furniture industry, boat building, interior design and décor but also in the production of toys made from natural materials and wooden accessories. The surface of flexible plywood, similarly to wood and traditional plywood, is easily processed and it can be waxed, painted, oiled and varnished. It can also be printed and, therefore, it can be used to produce invitations, business cards or labels. Flexible plywood can be processed with use of all the typical machines used for wood. Moreover, it can also be treated with a laser and a waterjet so that precise and complex elements, such as jewellery, toys or models can be manufactured. Last but not least, it can supplement other wood-based materials of high flexibility, e.g. MDF used for ski building. Manufacturing flexible plywood from domestic wood species would not only decrease the production and transport costs but it would also expand the resource base. Owing to the specific structure of flexible plywood, researchers look for such domestic wood species that can be used in the core layer and in the face layers. It is necessary to select material for the core layer from species of medium density and high bending strength, whereas the face layers must be made from wood species characterized by thin-walled cells, low density and high elasticity. Although none of the European species meets the first criterion, the literature on the subject as well the authors' investigations show that beech, pine, birch and alder attain the highest values of bending strength. The investigations conducted by both the authors and other researchers prove that it is possible to produce flexible plywood with use of veneers made from domestic species. The investigations by Borysiuk et al. $(2003,2007)$ made it possible to determine the effect of various wood species, i.e. pine, aspen, beech, on elastic properties of plywood made from them. The researchers found out that best results can be achieved when the centre layer is made from $0.8 \mathrm{~mm}$ thick pine veneer and the face layers are made from birch veneers. The previous studies conducted by the authors of the present paper also confirm that pine veneer is highly useful as the centre layer of flexible plywood. What is more, taking into account the fact that mechanical properties of plywood are strictly related with the strength properties of applied veneers, we determined bending strength and modulus of elasticity for veneers made form species such as alder, birch, beech, linden, poplar, willow, pine and spruce. Therefore, we have come to the conclusion that face layers of plywood with increased elasticity can be made from such wood species as poplar, linden, willow and spruce (Biadała et al. 2015).

The aim of the present work is to determine the possibility of applying domestic wood species to the production of both traditional and flexible plywood glued with PF resin. In the paper, we determine the effect of the wood species on the mechanical properties of the produced experimental plywood.

\section{MATERIALS AND METHODS}

\section{Raw materials}

In course of the research we used phenol-formaldehyde (PF) resin often applied as a bonding agent for OSB and water-resistant plywood. The characteristics of the resin was as follows: dry mass content $-49.5 \%$, viscosity $-760 \mathrm{mPa} \cdot \mathrm{s}$, density $-1.208 \mathrm{~g} \cdot \mathrm{cm}^{-3}, \mathrm{pH}-12.5$. The adhesive mixture was prepared according to industrial recipes, i.e. 13.6 parts by weight (PBW) of tannic filler/100 PBW of PF resin. 
Three-layer experimental panels were produced with use of veneers made from the following wood species: alder (Alnus glutinosa Gaertn.), beech (Betula pendula Roth), birch (Fagus sylvatica L.), pine (Pinus sylvestris L.), linden (Tilia cordata Mill.), poplar (Populus alba L.), willlow (Salix alba L.), spruce (Picea abies L.). The methods of plywood manufacturing as well as preparation of the material for research were presented in the previous study published by Biadała et al. (2015).

\section{Panels' production}

Plywood was produced in two variants. In variant I plywood was made of veneers with thickness of $1.7 \mathrm{~mm}$, obtained from various wood species. In variant II plywood was produced with use of long-grain wood of medium density and high bending strength in the core layer, and this veneer was thinner than the face layer veneers. In this variant, the core layer was made from pine veneer with thickness of $1.0 \mathrm{~mm}$, and the face layers were $1.4 \mathrm{~mm}$ thick, made from veneers from the other wood species. Variant 2 was an attempt to produce experimental plywood that would be alike $3 \mathrm{~mm}$-thick flexible plywood. Plywood was pressed with use of the following parameters: pressing time 5 minutes, pressing temperature $135^{\circ} \mathrm{C}$, unit pressure $1.4 \mathrm{~N} \cdot \mathrm{mm}^{-2}$, resin load $140 \mathrm{~g} \cdot \mathrm{m}^{-2}$.

\section{Experimental methods}

For the produced plywood we determined modulus of rupture (MOR) and modulus of elasticity at bending (MOE) both across $(\perp)$ and parallel to (II) the grain in the face layers according to the standard EN 310. We also determined the tensile strength (TS) across $(\perp)$ and parallel to (II) the grain and at the angle of $45^{\circ}$ according to EN-789. Taking into consideration the fact that wood species used in the investigation vary in terms of density, we determined the specific values of modulus of rupture (SMOR) and modulus of elasticity (SMOE) according to the following Eqs:

$$
\begin{array}{ll}
\text { SMOR }=\frac{\text { MOR }}{D_{i}} & (\mathrm{~km}) \\
\text { SMOE }=\frac{\text { MOE }}{D_{i}} & (\mathrm{~km})
\end{array}
$$

where: $\quad$ MOR - modulus of rupture $\left(\mathrm{N} \cdot \mathrm{mm}^{-2}\right)$

MOE - modulus of elasticity $\left(\mathrm{N} \cdot \mathrm{mm}^{-2}\right)$

$\mathrm{D}_{\mathrm{i}}-$ density of veneer $\left(\mathrm{kg} \cdot \mathrm{m}^{-3}\right)$.

Calculations of this type, applied also by other researchers, make it possible to compare modulus of rupture and elasticity of veneer or LVL made from wood species of various densities (Lee et al. 1999, Bao et al. 2001, Bal and Bektas 2012, 2014).

For the produced plywood, we also evaluated the bond quality by shear testing after soaking and boil test according to EN 314-1; the applied tests are required for class 3 quality of bond.

In order to determine the compression ratio $\mathrm{Sn}$ in the process of producing plywood from the investigated wood species we determined the nominal compression ratio according to the Eq. 3:

$$
S_{n}=\frac{h_{n}-h_{t}}{h_{n}} \times 100
$$

where: $h_{n}$ - nominal height of a set calculated as the sum of nominal thickness of veneer sheets $(\mathrm{mm})$,

$\mathrm{h}_{\mathrm{t}}$ - plywood thickness after conditioning $(\mathrm{mm})$. 


\section{Statistical analysis}

The results of studies on the physical and mechanical properties of the experimental boards were compiled and analysed statistically with use of STATISTICA software, version 13.1. To compare average values of physical and mechanical properties of investigated boards we carried out a one-way ANOVA (analysis of variance) and post hoc Tukey's test, and based on them homogenous groups of average values were determined for each investigated property, assuming that the statistical significance level $\mathrm{p}$ equals 0.05 .

\section{RESULTS AND DISCUSSION}

Tab. 1 shows the elasticity of plywood produced according to variant I, determined based on modulus of rupture (MOR) and modulus of elasticity (MOE) depending on the kind of applied wood. The results of investigations on the typical plywood materials, such as beech, birch, alder, are characteristic of plywood made from the investigated wood species. For these species the obtained values of MOR and MOE, both parallel to grain and across the grain, were the highest. Moreover, Tukey's test for homogenous groups shows that alder and birch plywood belong to virtually the same homogenous groups, which means that as for MOR and MOE (regardless of the test direction) there are no statistically significant differences between the two types of plywood. It is important due to the fact that alder is one of the most promising and yet still underused wood species in Europe (Bekhta and Sedliacik 2019). Moreover, Toksyn et al. (2006) found out that alder plywood shows lower strength properties than beech plywood. However, when the annual increments of beech and alder trees in 1 ha and the time they need to reach suitable diameters for the manufacturing rotary cut veneers were taken into consideration, it was calculated that alder trees allow 3.82 times additional physical harvesting than beech trees.

As expected, beech plywood was characterized by the highest values of bending strength and modulus of elasticity, especially parallel to the grain. It results from the fact that beech wood has higher density than other investigated wood species. These findings are confirmed by studies of other authors, who investigated wood of the following density: beech $0.69 \mathrm{~g} \cdot \mathrm{cm}^{-3}$, birch $0.61 \mathrm{~g} \cdot \mathrm{cm}^{-3}$, alder $0.59 \mathrm{~g} \cdot \mathrm{cm}^{-3}$, pine $0.49-0.53 \mathrm{~g} \cdot \mathrm{cm}^{-3}$ and poplar 0.39-0.46 $\mathrm{g} \cdot \mathrm{cm}^{-3}$ (Wilczyński and Wambier 2012, Bal and Bektas 2014, Ozturk et al. 2019). In these studies plywood produced from beech wood showed much higher values of bending strength and modulus of elasticity than those made from other kinds of wood. The results obtained from investigations conducted by Bal and Bektas (2014) may serve as an example: values of MOR and MOE for beech plywood parallel to the grain were 80.2 and $8258 \mathrm{~N} \cdot \mathrm{mm}^{-2}$, and for poplar plywood they were 56.6 and $67747 \mathrm{~N} \cdot \mathrm{mm}^{-2}$ (the tendency for the properties across the grain was similar). On the other hand, Cakiroglu et al. (2019) claim that beech plywood is more expensive than that made form birch, which is cheaper and at the same time it has good strength properties and a similar colour.

In case of other types of wood, i.e. linden, poplar, willow and spruce, values of these properties were considerably lower. 
Based on the analysis of data included in Tab. 1, we found out that plywood produced from linden, poplar and willow wood, which attained the lowest values of MOE across the grain, according to EN 636 can be classified as E5 modulus of elasticity class and as F10 modulus of rupture class. Whereas, beech plywood produced in the same conditions can be classified as E15 and F20 respectively.

These properties are quite different if we take into the account the density of plywood (Tab. 1). The lowest specific modulus of rupture (SMOR) and elasticity (SMOE) parallel to the grain is observed for the willow plywood.

Tab. 1: Bending strength and modulus of elasticity in bending of plywood produced according to variant I.

\begin{tabular}{|c|c|c|c|c|c|c|c|c|c|}
\hline \multirow{3}{*}{$\begin{array}{l}\text { Type of } \\
\text { plywood }\end{array}$} & \multirow{2}{*}{$\begin{array}{c}\text { Density of } \\
\text { plywood }\end{array}$} & MOR & MOE & MOR & MOE & SMOR & SMOE & SMOR & SMOE \\
\hline & & \multicolumn{2}{|c|}{ II } & \multicolumn{2}{|c|}{$\perp$} & \multicolumn{2}{|c|}{ II } & \multicolumn{2}{|c|}{$\perp$} \\
\hline & $\left(\mathbf{k g} \cdot \mathrm{m}^{-3}\right)$ & \multicolumn{4}{|c|}{$\left(\mathrm{N} \cdot \mathbf{m m}^{-2}\right)$} & \multicolumn{4}{|c|}{ (km) } \\
\hline Alder & 600 & $\begin{array}{c}125.3 \\
(3.7 \mathrm{c})^{*}\end{array}$ & $\begin{array}{l}11940 \\
(290 \text { a) }\end{array}$ & $\begin{array}{c}24.1 \\
(0.8 \mathrm{ab})\end{array}$ & $\begin{array}{c}1180 \\
(40 \mathrm{bc})\end{array}$ & $\begin{array}{c}21.3 \\
(0.6 \mathrm{bd})\end{array}$ & $\begin{array}{l}2030 \\
(50 \mathrm{a})\end{array}$ & $\begin{array}{c}4.1 \\
(0.1 \mathrm{a})\end{array}$ & $\begin{array}{c}201 \\
(6.7 \mathrm{~b})\end{array}$ \\
\hline Birch & 650 & $\begin{array}{l}137.6 \\
(9.2 \mathrm{c})\end{array}$ & $\begin{array}{c}11910 \\
(1030 \mathrm{a})\end{array}$ & $\begin{array}{c}24.0 \\
(1.0 \mathrm{ab})\end{array}$ & $\begin{array}{l}1200 \\
(40 \mathrm{c})\end{array}$ & $\begin{array}{l}21.6 \\
(1.4 \mathrm{~b})\end{array}$ & $\begin{array}{c}1870 \\
(160 \mathrm{ab})\end{array}$ & $\begin{array}{c}3.8 \\
(0.2 \mathrm{ab})\end{array}$ & $\begin{array}{c}187 \\
(12.8 \mathrm{bc})\end{array}$ \\
\hline Beech & 680 & $\begin{array}{l}158.4 \\
(7.2 \mathrm{~d})\end{array}$ & $\begin{array}{l}13720 \\
(680 \mathrm{~d})\end{array}$ & $\begin{array}{c}26.8 \\
(2.2 \mathrm{~b})\end{array}$ & $\begin{array}{c}1110 \\
(110 \mathrm{bc})\end{array}$ & $\begin{array}{l}23.8 \\
(1.1 \mathrm{~b})\end{array}$ & $\begin{array}{l}2060 \\
(100 \mathrm{a})\end{array}$ & $\begin{array}{c}4.02 \\
(0.34 \mathrm{a})\end{array}$ & $\begin{array}{c}167 \\
(16.3 \mathrm{ac})\end{array}$ \\
\hline Linden & 610 & $\begin{array}{c}91.9 \\
(4.1 \mathrm{ab})\end{array}$ & $\begin{array}{c}11890 \\
(1030 \mathrm{a})\end{array}$ & $\begin{array}{c}22.0 \\
(3.2 \mathrm{a})\end{array}$ & $\begin{array}{c}940 \\
(50 \mathrm{ae})\end{array}$ & $\begin{array}{l}15.4 \\
(0.7 \mathrm{a})\end{array}$ & $\begin{array}{c}1990 \\
(170 \mathrm{a})\end{array}$ & $\begin{array}{c}3.7 \\
(0.5 \mathrm{ab})\end{array}$ & $\begin{array}{c}154 \\
(8.2 \mathrm{a})\end{array}$ \\
\hline Poplar & 570 & $\begin{array}{c}105.5 \\
(12.9 \mathrm{~b})\end{array}$ & $\begin{array}{c}10500 \\
(1200 \mathrm{ab})\end{array}$ & $\begin{array}{c}20.6 \\
(2.1 \mathrm{a})\end{array}$ & $\begin{array}{c}820 \\
(70 \mathrm{de})\end{array}$ & $\begin{array}{c}18.8 \\
(18.9 \mathrm{~cd})\end{array}$ & $\begin{array}{c}1880 \\
(200 \mathrm{ab})\end{array}$ & $\begin{array}{c}3.7 \\
(0.34 \mathrm{ab})\end{array}$ & $\begin{array}{c}147 \\
(12.6 \mathrm{a})\end{array}$ \\
\hline Willow & 670 & $\begin{array}{c}79.9 \\
(7.4 \text { a) }\end{array}$ & $\begin{array}{l}8600 \\
(420 \mathrm{c})\end{array}$ & $\begin{array}{c}21.7 \\
(2.0 \mathrm{a})\end{array}$ & $\begin{array}{c}970 \\
(100 \mathrm{a})\end{array}$ & $\begin{array}{c}12.2 \\
(1.1 \mathrm{e})\end{array}$ & $\begin{array}{l}1310 \\
(60 \mathrm{c})\end{array}$ & $\begin{array}{c}3.3 \\
(0.3 \mathrm{~b})\end{array}$ & $\begin{array}{c}148 \\
(15.5 \mathrm{a})\end{array}$ \\
\hline Pine & 630 & $\begin{array}{c}105.9 \\
(5.62 \mathrm{~b})\end{array}$ & $\begin{array}{c}10610 \\
(850 \mathrm{ab})\end{array}$ & $\begin{array}{c}15.6 \\
(2.2 \mathrm{c})\end{array}$ & $\begin{array}{c}750 \\
(40 \mathrm{~d})\end{array}$ & $\begin{array}{c}17.1 \\
(0.9 \mathrm{ac})\end{array}$ & $\begin{array}{c}1720 \\
(140 \mathrm{~b})\end{array}$ & $\begin{array}{c}2.5 \\
(0.4 \mathrm{c})\end{array}$ & $\begin{array}{c}120 \\
(6.6 \mathrm{~d})\end{array}$ \\
\hline Spruce & 520 & $\begin{array}{c}78.9 \\
(8.4 \mathrm{a})\end{array}$ & $\begin{array}{c}9550 \\
(580 \mathrm{bc})\end{array}$ & $\begin{array}{c}21.7 \\
(3.1 \mathrm{a})\end{array}$ & $\begin{array}{c}1040 \\
(90 \mathrm{ab})\end{array}$ & $\begin{array}{c}15.5 \\
(1.7 \mathrm{a})\end{array}$ & $\begin{array}{c}1870 \\
(110 \mathrm{ab})\end{array}$ & $\begin{array}{c}4.3 \\
(0.6 \mathrm{a})\end{array}$ & $\begin{array}{c}204 \\
(1.5 \mathrm{~b})\end{array}$ \\
\hline
\end{tabular}

*standard deviation; a, b, c ... - homogenous groups according to Tukey's test $(\alpha=0.05)$.

The lowest values of MOR and MOE parallel to the grain were obtained for willow and spruce plywood; and the values attained for poplar plywood were similar to those of pine plywood (homogenous groups, $\mathrm{b}$ and $\mathrm{ab}$ respectively). The investigations on MOR and MOE across the grain do not show such significant differences between the particular wood species. Only for pine plywood we noted that the value of MOR was $42 \%$ lower than the highest value, which was obtained for beech plywood. Fig. 1 illustrates the percentage differences in the values of MOR and MOE for the all the other types of experimental plywood in relation to beech plywood, for which the best strength properties were obtained.

The post hoc analysis for this type of plywood generated homogenous groups (e and $c$ respectively) for which the statistical significance level $\mathrm{p}$ took values much lower than the assumed value of 0.05. Linden and spruce plywood showed values of SMOR and SMOE at a comparable level (SMOR - homogeneous group $a$, SMOE $-a$ or $a b$ ), which was only a little lower than that for willow plywood. On the other hand, plywood made from beech, birch and alder wood were characterized by much higher values of SMOR and SMOE than willow plywood: the growth in these values reached, respectively, approx. $48 \%$ and $36 \%$. For the investigations performed across the grain in the face layers, the lowest values of SMOR and SMOE were obtained for pine plywood while the highest were for alder and spruce. As for the latter types, the values of the parameters are at a similar level, which is proven by the post hoc analysis - homogenous groups, $a$ and $b$, respectively. 

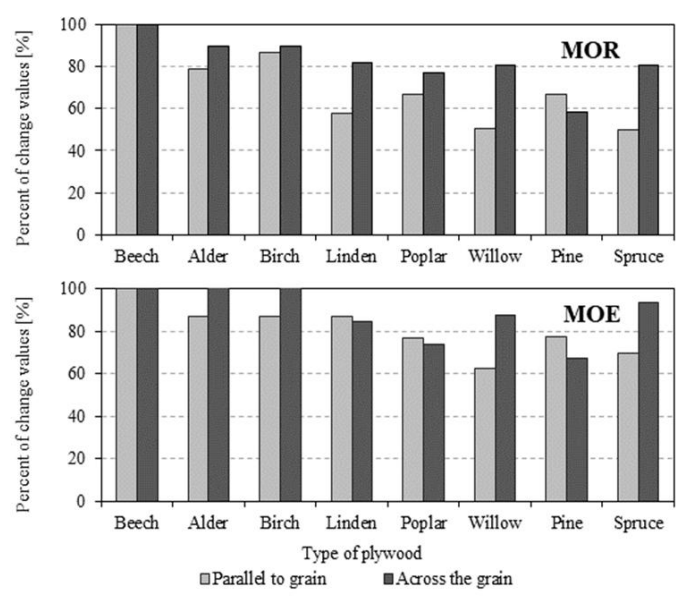

Fig. 1: Percentage changes in modulus of rupture (MOR) and modulus of elasticity (MOE) of investigated plywood in comparison with beech plywood.

The other types of plywood showed slightly lower values of SMOR and SMOE. Yet, for linden, poplar and willow plywood there were no statistically significant differences (homogenous groups $a$ and $a b$ ). The analysis of these results leads to the conclusion that properties of plywood made from linden, poplar and willow are most similar to that of flexible plywood.

Tab. 2 shows the properties of water-resistant plywood with increased elasticity made from veneer of various wood types according to variant II. Results of our investigations as well as works by other authors show that elastic properties of plywood depend on the wood species that the veneers are made from and their thickness and position in the structure of plywood (Kljak and Brezovic 2007, Biadała et al. 2015, Muhammad-Fitri et al. 2018). Therefore, at this stage of studies plywood was produced with use of $1.0 \mathrm{~mm}$ thick pine veneer in the centre layer and $1.4 \mathrm{~mm}$ thick face veneers made from various wood species.

The change in the structure of plywood and substituting centre veneer of a given wood type with pine veneer significantly affected the values of modulus of rupture and the modulus of elasticity of the produced experimental plywood.

As for linden, willow and spruce plywood, when compared with plywood produced according to variant $\mathrm{I}$, there is an increase in the values of MOR and MOE determined parallel the grain in the face layers of the plywood. These parameters, especially MOR, differ considerably which was confirmed by post hoc analysis in which three homogenous groups were determined (a, c and d). It is accompanied by analogous changes in the values of SMOR and SMOE taking into consideration the density of the particular types of plywood. On the other hand, plywood made from birch and beech wood was characterised by values of MOR parallel to grain comparable to those for plywood produced from the same wood types according to variant I. The highest values of MOR and MOE parallel to grain were obtained for beech and linden veneer and the lowest were for poplar plywood. However, considering the values of modulus of rupture and modulus of elasticity across the grain in the face layer of the plywood, we observe that plywood manufactured according to variant II shows significant decrease in these parameters regardless of the applied material. 
Tab. 2: Bending strength and modulus of elasticity in bending of plywood produced according to variant II.

\begin{tabular}{|c|c|c|c|c|c|c|c|c|c|}
\hline \multirow{3}{*}{$\begin{array}{l}\text { Type of } \\
\text { plywood }\end{array}$} & \multirow{2}{*}{$\begin{array}{c}\text { Density of } \\
\text { plywood }\end{array}$} & MOR & MOE & MOR & MOE & SMOR & SMOE & SMOR & SMOE \\
\hline & & \multicolumn{2}{|c|}{ II } & \multicolumn{2}{|c|}{$\perp$} & \multicolumn{2}{|c|}{ II } & \multicolumn{2}{|c|}{$\perp$} \\
\hline & $\left(\mathrm{kg} \cdot \mathrm{m}^{-3}\right)$ & \multicolumn{4}{|c|}{$\left(\mathrm{N} \cdot \mathrm{mm}^{-2}\right)$} & \multicolumn{4}{|c|}{ (km) } \\
\hline Alder & 520 & $\begin{array}{c}95.6 \\
(3.6 \mathrm{ab})^{*}\end{array}$ & $\begin{array}{c}10400 \\
(1030 \mathrm{a})\end{array}$ & $\begin{array}{c}16.6 \\
(0.9 \mathrm{ab})\end{array}$ & $\begin{array}{c}800 \\
(40 \mathrm{~b})\end{array}$ & $\begin{array}{c}18.7 \\
(0.7 \mathrm{a})\end{array}$ & $\begin{array}{c}2040 \\
(200 \mathrm{a})\end{array}$ & $\begin{array}{c}3.25 \\
(0.2 \mathrm{c})\end{array}$ & $\begin{array}{c}157 \\
(7.3 \mathrm{~d})\end{array}$ \\
\hline Birch & 640 & $\begin{array}{c}130.0 \\
(10.7 \mathrm{~cd})\end{array}$ & $\begin{array}{c}14390 \\
(1590 \mathrm{~b})\end{array}$ & $\begin{array}{c}17.3 \\
(2.1 \mathrm{~b})\end{array}$ & $\begin{array}{c}850 \\
(110 \mathrm{~b})\end{array}$ & $\begin{array}{c}20.7 \\
(1.6 \mathrm{bc})\end{array}$ & $\begin{array}{c}2730 \\
(350 \mathrm{c})\end{array}$ & $\begin{array}{c}3.40 \\
(0.4 \mathrm{c})\end{array}$ & $\begin{array}{c}167 \\
(22.4 \mathrm{~d})\end{array}$ \\
\hline Beech & 760 & $\begin{array}{c}156.4 \\
(7.2 \mathrm{e})\end{array}$ & $\begin{array}{l}16690 \\
(940 \mathrm{c})\end{array}$ & $\begin{array}{c}16.1 \\
(0.8 \mathrm{ab})\end{array}$ & $\begin{array}{c}870 \\
(110 \mathrm{~b})\end{array}$ & $\begin{array}{c}21.0 \\
(1.0 \mathrm{bc})\end{array}$ & $\begin{array}{c}2240 \\
(130 a)\end{array}$ & $\begin{array}{c}2.2 \\
(0.1 \mathrm{a})\end{array}$ & $\begin{array}{c}116 \\
(14.3 \mathrm{a})\end{array}$ \\
\hline Linden & 740 & $\begin{array}{l}139.9 \\
(6.1 \mathrm{~d})\end{array}$ & $\begin{array}{c}16230 \\
(730 \mathrm{bc})\end{array}$ & $\begin{array}{c}10.9 \\
(1.3 \mathrm{c})\end{array}$ & $\begin{array}{c}500 \\
(50 \mathrm{a})\end{array}$ & $\begin{array}{c}19.3 \\
(0.9 \mathrm{ab})\end{array}$ & $\begin{array}{c}2260 \\
(100 a)\end{array}$ & $\begin{array}{c}1.5 \\
(0.2 \mathrm{~b})\end{array}$ & $\begin{array}{c}69 \\
(6.8 \mathrm{bc})\end{array}$ \\
\hline Poplar & 640 & $\begin{array}{c}85.1 \\
(5.7 \mathrm{a})\end{array}$ & $\begin{array}{c}9940 \\
(1090 \text { a) }\end{array}$ & $\begin{array}{c}8.0 \\
(0.3 \mathrm{e})\end{array}$ & $\begin{array}{c}290 \\
(30 \mathrm{c})\end{array}$ & $\begin{array}{c}13.6 \\
(0.9 \mathrm{~d})\end{array}$ & $\begin{array}{c}1580 \\
(170 \mathrm{~b})\end{array}$ & $\begin{array}{c}1.3 \\
(0.1 \mathrm{~b})\end{array}$ & $\begin{array}{c}46 \\
(4.8 \mathrm{~b})\end{array}$ \\
\hline Willow & 560 & $\begin{array}{c}97.7 \\
(5.7 \mathrm{~b})\end{array}$ & $\begin{array}{c}10430 \\
(1450 \mathrm{a})\end{array}$ & $\begin{array}{c}12.5 \\
(0.7 \mathrm{~cd})\end{array}$ & $\begin{array}{c}510 \\
(80 \mathrm{a})\end{array}$ & $\begin{array}{c}17.8 \\
(1.0 \mathrm{a})\end{array}$ & $\begin{array}{c}1900 \\
(260 \mathrm{ab})\end{array}$ & $\begin{array}{c}2.3 \\
(0.1 \mathrm{a})\end{array}$ & $\begin{array}{c}93 \\
(14.4 \mathrm{a})\end{array}$ \\
\hline Spruce & 590 & $\begin{array}{l}125.0 \\
(6.3 \mathrm{c})\end{array}$ & $\begin{array}{c}16290 \\
\left(\begin{array}{ll}1 & 050 \\
b c\end{array}\right)\end{array}$ & $\begin{array}{c}14.5 \\
(1.7 \mathrm{ad})\end{array}$ & $\begin{array}{c}560 \\
(80 a)\end{array}$ & $\begin{array}{c}21.6 \\
(1.1 \mathrm{c})\end{array}$ & $\begin{array}{c}2810 \\
(180 \mathrm{c})\end{array}$ & $\begin{array}{c}2.5 \\
(0.3 \mathrm{a})\end{array}$ & $\begin{array}{c}96 \\
(13.4 \mathrm{a})\end{array}$ \\
\hline
\end{tabular}

*Standard deviation; $\mathrm{a}, \mathrm{b}, \mathrm{c} \ldots$ - homogenus groups according to Tukey's test $(\alpha=0.05)$.

The most substantial changes in values of MOR and MOE and, in consequence, SMOR and SMOE were observed in case of linden and poplar plywood. For linden plywood the value of bending strength is $10.9 \mathrm{~N} \cdot \mathrm{mm}^{-2}$ and the values of modulus of elasticity is $500 \mathrm{~N} \cdot \mathrm{mm}^{-2}$. In case of poplar plywood these parameters are lower, i.e. 8.0 and $290 \mathrm{~N} \cdot \mathrm{mm}^{-2}$, respectively. The other types of plywood were characterized by much higher bend strength and stiffness, especially alder, birch and beech plywood, whose strength properties were at a similar level (the post hoc analysis did not indicate statistically significant differences). For these types of plywood values of MOR varied from 16.1 to $17.3 \mathrm{~N} \cdot \mathrm{mm}^{-2}$ and of MOE from 800 to $870 \mathrm{~N} \cdot \mathrm{mm}^{-2}$. The recorded values of SMOR and SOME were also high and ranged from 2.2 to 3.4 and from 116 to $167 \mathrm{~km}$.

It is also noteworthy that the lowest values of strength parameters, i.e. MOR and MOE as well as SMOR and SMOE, regardless of the test direction, were obtained mainly by poplar plywood, and next by linden. Low values of these parameters, especially across the grain, were attained for willow plywood: MOE and MOR amounted to 12.5 and $510 \mathrm{~N} \cdot \mathrm{mm}^{-2}$. Similar results were obtained by Bal and Bektas (2014), who compared properties of plywood made from poplar, eucalyptus and beech. Therefore, it is reasonable to conclude that the change in the structure of plywood has enhanced its elasticity and the optimum types of wood to apply as face veneers are linden, poplar and willow. All these findings correspond with results of earlier research works done by the authors of the present paper (Biadała et al. 2015).

Tab. 3 shows results of investigations on tensile strength of the produced plywood depending on the structure (variant I and II) and the wood species used for the veneers.

The obtained values are very high, however, the values attained for plywood according to variant II are noticeably lower, especially those determined in the across-the-grain direction. It is because the core layer is made from pine wood, which as other coniferous species attains low values of tensile strength across the grain. It also explains low values of TS for pine plywood, regardless of the test direction. The fact that veneer position in the structure of plywood affects the tensile strength is confirmed by investigations by Popovska et al. (2017). 
Tab. 3: Tensile strength of experimental plywood.

\begin{tabular}{|l|c|c|c|c|c|c|}
\hline \multirow{3}{*}{$\begin{array}{l}\text { Type of } \\
\text { plywood }\end{array}$} & \multicolumn{6}{|c|}{ TS (N-mm-2) } \\
\cline { 2 - 7 } & \multicolumn{3}{|c|}{ Variant I } & \multicolumn{3}{c|}{ Variant II } \\
\cline { 2 - 7 } & $\begin{array}{c}\text { At the angle } \\
\text { of 45 }\end{array}$ & $\begin{array}{c}\text { Parallel to } \\
\text { grain }\end{array}$ & $\begin{array}{c}\text { Across the } \\
\text { grain }\end{array}$ & $\begin{array}{c}\text { At the angle } \\
\text { of 45 }\end{array}$ & $\begin{array}{c}\text { Parallel to } \\
\text { grain }\end{array}$ & $\begin{array}{c}\text { Across the } \\
\text { grain }\end{array}$ \\
\hline Alder & 22.11 & 69.33 & 41.19 & 16.60 & 57.52 & 26.76 \\
& $(3.14 \mathrm{abc})^{*}$ & $(8.18 \mathrm{a})$ & $(3.51 \mathrm{a})$ & $(2.34 \mathrm{ab})$ & $(5.97 \mathrm{a})$ & $(2.89 \mathrm{a})$ \\
Birch & 25.61 & 78.84 & 41.83 & 23.45 & 96.01 & 25.21 \\
& $(2.46 \mathrm{~cd})$ & $(7.94 \mathrm{ab})$ & $(3.26 \mathrm{a})$ & $(1.72 \mathrm{~d})$ & $(7.14 \mathrm{c})$ & $(1.74 \mathrm{a})$ \\
Beech & 19.32 & 81.66 & 45.82 & 16.75 & 115.72 & 35.18 \\
& $(3.37 \mathrm{ab})$ & $(5.18 \mathrm{bd})$ & $(3.24 \mathrm{ab})$ & $(1.00 \mathrm{ab})$ & $(8.77 \mathrm{~d})$ & $(4.23)$ \\
Linden & 22.81 & 100.02 & 45.71 & 19.80 & 69.01 & 27.60 \\
& $(2.87 \mathrm{abc})$ & $(2.79 \mathrm{~d})$ & $(2.48 \mathrm{ab})$ & $(1.37 \mathrm{bc})$ & $(3.60 \mathrm{a})$ & $(2.50 \mathrm{a})$ \\
Poplar & 30.42 & 75.47 & 51.91 & 15.05 & 61.07 & 18.80 \\
& $(2.80 \mathrm{~d})$ & $(6.92 \mathrm{ab})$ & $(3.07 \mathrm{ab})$ & $(1.49 \mathrm{a})$ & $(2.86 \mathrm{a})$ & $(1.90 \mathrm{~b})$ \\
Willow & 25.68 & 72.32 & 53.72 & 22.96 & 37.38 & 16.97 \\
& $(3.97 \mathrm{abcd})$ & $(0.53 \mathrm{ab})$ & $(9.36 \mathrm{~b})$ & $(1.53 \mathrm{~cd})$ & $(0.85 \mathrm{~b})$ & $(1.35 \mathrm{~b})$ \\
Pine & 18.92 & 52.17 & 26.21 & - & - & - \\
& $(2.20 \mathrm{a})$ & $(9.03 \mathrm{c})$ & $(5.80 \mathrm{c})$ & & & \\
Spruce & 26.66 & 62.87 & 25.60 & 17.67 & 55.73 & 29.25 \\
& $(2.49 \mathrm{bcd})$ & $(4.80 \mathrm{ac})$ & $(3.92 \mathrm{c})$ & $(1.00 \mathrm{ab})$ & $(1.15 \mathrm{a})$ & $(0.95 \mathrm{a})$ \\
\hline
\end{tabular}

*Standard deviation; a, b, c ... - homogenus groups according to Tukey's test $(\alpha=0.05)$.

The bond quality of veneers is a significant factor that affects the physical and mechanical properties of plywood. It depends on the characteristics of veneer surface, their moisture content, thickness, species and structure of wood, type and amount of adhesive and pressing conditions (Aydin et al. 2006, Bekhta et al. 2009, Srajer et al. 2013). Thicker veneers and those of lower density tend to absorb more resin and, as a result, the curing process occurs in the veneer rather than in the glue line (Muniz et al. 2013, Muhammad-Fitri et al. 2018). Taking into account the fact that the investigated veneers were made from various wood species of various density and thickness, the produced plywood was subjected to investigations on bond quality by determining their shear strength after boiling and soaking tests. Results of these investigations are presented in Tab. 4.

Tab. 4: Bond quality of experimental plywood.

\begin{tabular}{|l|c|c|c|c|}
\hline \multirow{2}{*}{$\begin{array}{c}\text { Type of } \\
\text { plywood }\end{array}$} & \multicolumn{4}{|c|}{$\mathbf{f v}\left(\mathbf{N} \cdot \mathbf{m m}^{-2}\right)$} \\
\cline { 2 - 5 } & \multicolumn{2}{|c|}{ Variant I } & \multicolumn{2}{c|}{ Variant II } \\
\cline { 2 - 5 } & Soaking & Boiling test & Soaking & Boiling test \\
\hline Alder & $2.36(0.30 \mathrm{~b})^{*}$ & $2.04(0.66 \mathrm{abc})$ & $2.04(0.22 \mathrm{a})$ & $1.90(0.33 \mathrm{ab})$ \\
\hline Birch & $3.27(0.43 \mathrm{~d})$ & $2.47(0.17 \mathrm{~d})$ & $2.69(0.56 \mathrm{~b})$ & $2.66(0.37 \mathrm{~d})$ \\
\hline Beech & $2.99(0.45 \mathrm{~cd})$ & $2.44(0.7 \mathrm{~cd})$ & $2.30(0.45 \mathrm{ab})$ & $2.16(0.35 \mathrm{ac})$ \\
\hline Linden & $2.57(0.36 \mathrm{bc})$ & $2.15(0.23 \mathrm{bcd})$ & $2.62(0.29 \mathrm{~b})$ & $2.50(0.43 \mathrm{~cd})$ \\
\hline Poplar & $2.40(0.30 \mathrm{~b})$ & $1.86(0.22 \mathrm{ab})$ & $2.24(0.31 \mathrm{ab})$ & $1.91(0.27 \mathrm{ab})$ \\
\hline Willow & $1.81(0.14 \mathrm{a})$ & $1.67(0.23 \mathrm{ab})$ & $1.87(0.25 \mathrm{a})$ & $1.67(0.23 \mathrm{~b})$ \\
\hline Pine & $1.71(0.19 \mathrm{a})$ & $1.63(0.16 \mathrm{a})$ & - & - \\
\hline Spruce & $1.89(0.21 \mathrm{a})$ & $1.70(0.22 \mathrm{ab})$ & $2.32(0.36 \mathrm{ab})$ & $2.25(0.28 \mathrm{acd})$ \\
\hline
\end{tabular}

*Standard deviation; $\mathrm{a}, \mathrm{b}, \mathrm{c} \ldots$ - homogenus groups according to Tukey's test $(\alpha=0.05)$.

All the presented values significantly exceed $1 \mathrm{~N} \cdot \mathrm{mm}^{-2}$; that is why, we decided not to analyse the image of bend shearing. However, the investigation shows that plywood produced 
according to variant I from poplar, willow pine and spruce is characterised by the lowest bond quality, significantly lower than other investigated species; the latter three show similar level of bond quality (homogeneous group a after soak test and a or ab after double boil test). This phenomenon can be explained by the fact that owing to lower density of these species the resin can more easily penetrate into wood tissue (Mansouri et al. 2006, Cakiroglu et al. 2019). The shear strength determined after soaking and boiling test ( $\mathrm{fv}$ ) for these three types of plywood (willow, pine and spruce) varied from 1.71 to $1.89 \mathrm{~N} \cdot \mathrm{mm}^{-2}$ after soaking and from 1.63 to $1.70 \mathrm{~N} \cdot \mathrm{mm}^{-2}$ after double boiling test. As expected, the best gluability was observed for beech and birch plywood - the value of $\mathrm{fv}$ reached 2.99 and $3.27 \mathrm{~N} \cdot \mathrm{mm}^{-2}$ after soaking and 2.44 and $2.27 \mathrm{~N} \cdot \mathrm{mm}^{-2}$ after double boiling test. Such results correspond with works by other authors. For example, Bal and Bektas (2014) after boing test attained the values of shear strength of $2.44 \mathrm{~N} \cdot \mathrm{mm}^{-2}$ for beech plywood and $1.37 \mathrm{~N} \cdot \mathrm{mm}^{-2}$ for poplar plywood. The bond quality for polar plywood attained by Öncel et al. (2019) was at the similar level. Cakiroglu et al. (2019) with use of MUPF resin produced beech and birch plywood whose shear strength was $3.87 \mathrm{~N} \cdot \mathrm{mm}^{-2}$ and $3.06 \mathrm{~N} \cdot \mathrm{mm}^{-2}$ respectively. Investigations by Toksoy et al. (2006) showed that shear strength after 24 hour soaking for alder plywood was $2.54 \mathrm{~N} \cdot \mathrm{mm}^{-2}$ and for beech plywood it was $2.75 \mathrm{~N} \cdot \mathrm{mm}^{-2}$.

The manufacturing of plywood according to of variant II, with use of pine veneer in the core layer, leads to the decrease in the average value of shear strength in case of plywood whose face layers were made from alder, birch and beech veneer. The most significant decrease in the bond quality was observed for beech plywood: the average values of fv after soaking fell by $23 \%$ and after boiling by $11 \%$. As for linden, poplar and spruce plywood, the bond quality has considerably improved. The greatest improvement of gluability was observed for spruce plywood, whose fv values, deepening on the conducted test, increased by approx. $20 \%$ and $25 \%$. The quality of willow plywood remained practically the same. Investigations by Muzin et al. (2013) prove that using wood of higher density in the core layer favourably affects the bond quality. It results from the obvious fact that wood of higher density is characterized by better shear strength ( $\mathrm{Bal}$ 2016). That is why, in comparison to variant I, plywood produced according to variant 2 , with face layers made from low density wood, such as linden, willow and spruce, shows better bond quality if the core layer is substituted with higher density pine veneer. Similar observations were made by Bal and Bektas (2014), Muhammad-Fitri et al. (2018) and Cakiroglu et a. (2019).

In the course of investigations, we applied the same value of pressure, i.e. $1.4 \mathrm{~N} \cdot \mathrm{mm}^{-2}$, regardless of the type of wood and variant of manufacturing. When selecting the value of pressure it is crucial to make sure it allows both veneers to adhere evenly and therefore attain required bond quality. On the other hand, the pressing pressure should be quite low so that the thickness of the produced material is not decreased. It may result in an adverse growth of the specific weight of plywood and decrease in the material yield of the whole production process. The compression ratio is a resultant value depending on several technological factors: not only on the pressing pressure, but also moisture content and density of the material ( $\mathrm{Bal} 2016$ ). That is why, to provide a better characteristic of the produced experimental plywood, we determined their compression ratio, which is a crucial parameter from the technological point of view, especially when alternative materials are used. The results of tests on the compression ratio $(\mathrm{Sn})$ of the investigated experimental boards are shown in Fig. 2. They prove that for plywood produced according to variant I the highest compression ratio is attained by willow, poplar, pine and spruce plywood.

It results from the fact that they are made from wood of lower density than that commonly used in industry, such as birch, alder and beech, which are species of higher density. In case of willow plywood, the recorded Sn value is twice as high as that for birch or beech plywood. Similar observation were made by Bal (2016) who produced LVL with use of two veneers of two wood 
species (poplar and eucalyptus) of different density. The author concluded that when using the same pressure, the compression ratio for wood of lower density is higher than in case of wood characterized by higher density.

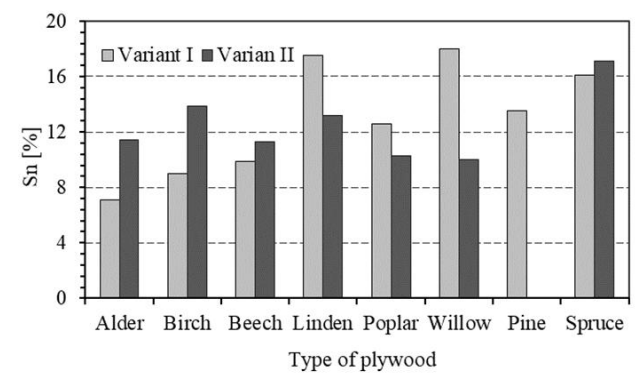

Fig.2: Compression ratio of experimental plywood depending on its structure and applied type of wood.

In the variant 2 of investigations, the change in the structure of plywood as well as the substitution of veneers in the core layer led to a significant increase in the compression ratio of alder, beech and birch plywood. This phenomenon results from the fact that the core layer is made from pine, which also leads to the decrease in $\mathrm{Sn}\urcorner$ value for linden, poplar and willow plywood.

\section{CONCLUSIONS}

1. Taking into consideration the density and modulus of elasticity, European species such as poplar, linden and willow are the most suitable types of wood to be used as face layers of plywood. In comparison with beech, birch and alder, plywood made from these species shows lower values of modulus of rupture, tensile strength and bond quality. Yet, values of these properties are still at an acceptable level.

2. It is possible to use these species in manufacturing plywood of increased elasticity purposed for use in humid conditions. Although the plywood shows a decrease in shear strength after boiling and double boiling test, the bond quality meets requirements of the EN 314-2 standard for plywood purposed for use in humid conditions $\left(\mathrm{fv}>1 \mathrm{~N} \cdot \mathrm{mm}^{-2}\right)$.

3. Plywood produced from linden, poplar and willow veneers was characterized by higher compression ratio than that made from beech, birch and alder, which is quite an unfavourable feature as far as material efficiency is concerned.

4. The analysis of the attained results leads to the conclusion that the values of specific modulus of rupture and modulus of elasticity (SMOR and SMOE) may be an important index, which can be used to compare the elastic properties of plywood produced from wood of various density.

\section{REFERENCES}

1. Aydin, I., Colakoglu, G., Colak, S., Demirkir, C., 2006. Effects of moisture content on formaldehyde emission and mechanical properties of plywood. Building and Environment 41: 1311-1316. 
2. Bal, B.C., Bektas, I., 2012: The effects of wood species, load direction, and adhesives on bending properties of laminated veneer lumber. BioResources 7(3): 3104-3112.

3. Bal, B.C., Bektas, I., 2014: Some mechanical properties of plywood produced from eucalyptus, beech, and poplar veneer. Maderas: Ciencia y Tecnologia 16(1): 99-108.

4. Bal, B.C., 2016: Some mechanical properties of laminated veneer lumber produced with fast-growing Poplar and Eucalyptus. Maderas: Ciencia y Tecnologia 18(3): 413-424.

5. Bao, F., Fu, F., Choong, E.T., Hse, C., 2001: Contribution factor of wood properties of three poplar clones to strength of laminated veneer lumber. Wood and Fiber Science 33(3): 345-352.

6. Bekhta, P., Hiziroglu, S., Potapova, O., Sedliacik, J., 2009: Shear strength of exterior plywood panels pressed at low temperature. Materials 2: 876-882.

7. Bekhta, P., Sedliacik, J., 2019: Environmentally-friendly high-density polyethylene-bonded plywood panels. Polymer 11(7): 1166.

8. Biadała, T., Czarnecki, R., Dukarska, D., 2015: Attempt to produce flexible plywood with use of European wood species. Wood Research 60(2): 317-328.

9. Borysiuk, P., Zado, A., Sosińska, K., Gowin, Ł., Mrozik, M., Nowakowski, M., 2003: Flexible plywood made of Polish timber. Annals of Warsaw Agricultural University. Forestry and Wood Technology 53: 23-27.

10. Borysiuk, P., Dziurka, D., Jabłoński, M., Sosińska, K., 2007: Selected properties of flexible plywood made of domestic wood species. Annals of Warsaw University of Life Sciences SGGW. Forestry and Wood Technology 61: 71-74.

11. Cakiroglu, E.O, Demir A., Aydin, I., 2019: Comparison of birch and beech wood in terms of economic and technological properties for plywood manufacturing. Drvna Industrija 70(2): 169-174.

12. EN 310, 1993 Wood-based panels. Determination of modulus of elasticity in bending and of bending strength.

13. EN 314-1, 2004 Plywood. Bond Quality. Test methods.

14. EN 314-2, 2008 Plywood. Bond Quality. Requirements.

15. EN 636, 2012 Plywood. Specification.

16. Iwakiri, S., de Matos, J.L.M., Prata, J.G., Trianoski, R., da Silva, L.S., 2013: Evaluation of the use potential of nine species of genus eucalyptus for production of veneers and plywood panels. Cerne 19(2): 263-269.

17. Iwakiri, S., Neto, A.R., de Almeida, C.A., Biasi, C.P., Chies, D., Guisantes, F.P., Franzoni, J.A., Rigatto, P.A., Bettega, W.P., 2006: Evaluation of quality of phenolic plywood manufactured from Eucalyptus grandis. Ciencia Florestal 16(3-4): 437-443.

18. Iwakiri, S., Trianoski, R., Vieira, H.C., Andrade, R., Rocha, T.M.S., Ferreira, V.R.S., 2018: Viability of the use of wood of Cupressus torulosa for plywood production. Scientia Forestalis 46(120): 638-645.

19. Kljak, J., Brezovic, M., Jambrekovic, V., 2006: Plywood stress optimisation using the finite element method. Wood Research 51(1): 1-10.

20. Kljak, J., Brezovic, M., 2007: Influence of plywood structure on sandwich panel properties: Variability of veneer thickness ratio. Wood Research 52 (2): 77-88.

21. Knudson, R., Brunette, G., 2015: Evaluation of Canadian Prairie-Grown hybrid poplar for high value solid wood products. Forestry Chronicle 91(2):141-149.

22. Lee, J.N., Tang, R.C., Kaiserlik, J.H., 1999: Edge static bending properties of yellow-poplar laminated veneer lumber: effect of veneer-joint designs. Forest Product Journal 49(7-8): 64-70. 
23. Mansouri, H.M., Pizzi, A., Leban, J.M., 2006: Improved water resistance of UF adhesives for plywood by small pMDI additions. Holz als Roh- und Werkstoff 64: 218-220.

24. Muhammad-Fitri, S., Suffian, M., Wan-Mohd-Nazri, W. A. R., Nor-Yuziah, Y., 2018: Mechanical properties of plywood from batai (Paraserianthes falcataria), eucalyptus (Eucalyptus pellita) and kelempayan (Neolamarckia cadamba) with different layer and species arrangement. Journal of Tropical Forest Science 30(1): 58-66.

25. Muniz, G.I.B., Iwakiri, S., Viana, L.C., Andrade, M., Weber, C., Almeida, V.C., 2013: Production of plywood panels from Pinus taeda using veneers of differing densities and phenol-formaldehyde resin with high and low molecular weights. Cerne 19(2): 315-321.

26. Öncel, M., Vurdu, H., Aydoğan, H., 2019: The tensile shear strength of outdoor type plywood produced from fir, alnus, pine and poplar wood. Wood Research 64(5): 913-920.

27. Ozturk, H., Demir, A., Demirkir, C., Colakoglu, G., 2019: Effect of veneer drying process on some technological properties of polystyrene composite plywood panels. Drvna Industrija 70 (4): 369-376.

28. Peker, H., Tan, H., 2014. The effect of growth conditions, steaming, drying temperature, number of layers and type of adhesives on the some mechanical properties of plywoods produced from Spruce. Journal of Forestry Research 1(1A): 50-59.

29. Popovska, V.J., Iliev, B., Zlateski, G., 2017: Impact of veneer layouts on plywood tensile strength. Drvna Industrija 68(2): 153-161.

30. Shukla, S.R., Kamdem, D.P., 2008: Properties of laminated veneer lumber (LVL) made with low density hardwood species: effect of the pressure duration. Holz als Roh- und Werkstoff 66: 119-127.

31. Šrajer, J., Král, P., Čermák M., Mazal P., 2013: Structure evaluation of compressing of spruce and beech plywoods. Part 1: Microscopic structure. Wood Research 58(1): 101-112.

32. Toksoy, D., Colakoglu, G., Aydin, I., Colak, S., Demirkir, C., 2006: Technological and economic comparison of the usage of beech and alder wood in plywood and laminated veneer lumber manufacturing. Building and Environment 41(7): 872-876.

33. Wilczyński, M., Warmbier, K., 2012: Elastic moduli of veneers in pine and beech plywood. Drewno 55(188): 47-58.

\author{
Tomasz Biadaea, Rafae Czarnecki*, Dorota Dukarska* \\ Department of Wood Based Materials \\ Faculty of Wood Technology \\ Poznan University of Life Sciences \\ Wojska Polskiego Street 38/42 \\ 6o-637 Poznań \\ Poland.
}

*Corresponding authors: rczarnec@up.poznan.pl and ddukar@up.poznan.pl 
